\title{
Investigating the role played by social support in the association between religiosity and mental health in low income older adults: results from the São Paulo Ageing \& Health Study (SPAH)
}

\section{Investigando o papel do suporte social na associação entre religiosidade e saúde mental em idosos de baixa renda: resultados do São Paulo Ageing \& Health Study (SPAH)}

\author{
Alexandre Augusto Macêdo Corrêa, , 2,3 Alexander Moreira-Almeida, ,2 Paulo R. Menezes, ${ }^{4}$ \\ Homero Vallada, ${ }^{5,6}$ Marcia Scazufca ${ }^{6}$ \\ ${ }^{1}$ School of Medicine, Universidade Federal de Juiz de Fora (UFJF), Juiz de Fora, MG, Brazil \\ ${ }^{2}$ Center for Research in Spirituality and Health (NUPES), Universidade Federal de Juiz de Fora (UFJF), Juiz de Fora, MG, Brazil \\ ${ }^{3}$ Universidade Presidente Antônio Carlos (UNIPAC), Ubá, MG, Brazil \\ ${ }^{4}$ Department of Preventive Medicine, School of Medicine, Universidade de São Paulo (USP), São Paulo, SP, Brazil \\ ${ }^{5}$ Department of Psychiatry, Universidade de São Paulo (USP), São Paulo, SP, Brazil \\ ${ }^{6}$ Laboratório de Psicofarmacologia, Psicopatologia Experimental E Terapêutica Psiquiátrica (LIM-23), School of Medicine, Universidade de São \\ Paulo (USP), São Paulo, SP, Brazil
}

\begin{abstract}
Objective: Religiosity has been associated with mental health, especially in the elderly. There is a shortage of studies on the factors that mediate this association, including social support. The aim of this study was to assess the association between the various dimensions of religiosity and the prevalence of common mental disorders among the elderly, and to verify whether social support can work as a mechanism that explains such mediation. Method: The sample consisted of an elderly population living in a low income region of the city of São Paulo $(\mathrm{N}=1,980)$. Data on the socio-demographic profile of this population and on the prevalence of common mental disorders were collected, and indicators of religiosity and social support were identified. Results: $90.7 \%$ of the sample considered themselves to be religious. In terms of denomination, $66.6 \%$ were Catholic. Forty-one per cent attended some kind of religious activity at least once or more times a week. The presence of common mental disorders was not associated with religious affiliation or subjective religiosity. The prevalence of common mental disorders in followers attending religious services was approximately half (OR between 0.43 and $0.55, \mathrm{p}<0.001)$ compared to those who never attend a religious service. Attending religious services was associated with higher levels of social support. The association between a higher attendance frequency and fewer common mental disorders did not change after the inclusion of relevant of social support variables. Conclusion: The study showed that subjects presented high levels of religiosity and that there is a strong association between religious attendance and the prevalence of common mental disorders, which could not be explained by social support.
\end{abstract}

Descriptors: Spirituality; Elderly; Mental health; Social support; Mental health

\section{Resumo}

Objetivo: A religiosidade tem sido associada à saúde física e mental com especial importância na população idosa. Existe uma carência de estudos abordando os mediadores desta associação, dentre eles o suporte social. $O$ objetivo deste trabalho é analisar a associação entre dimensōes de religiosidade e prevalência de transtornos mentais comuns entre idosos e testar o suporte social como mecanismo de mediação desta suposta associação. Método: A amostra foi constituida pela população idosa de uma regiāo de baixa renda de São Paulo $(N=1.980)$. Foram coletados dados sociodemográficos, suporte social, indicadores de religiosidade e prevalência de transtorno mental comum. Resultados: 90,7\% da amostra considerou-se religiosa (66,6\% Católica); 41,2\% frequentam uma ou mais vezes alguma atividade religiosa semanalmente. A presença de transtorno mental comum não foi associada com filiaçāo religiosa ou considerar-se religioso. A prevalência de transtorno mental comum para os que frequentam serviço religioso foi aproximadamente a metade (OR entre 0,43 e 0,55, $p<0,001$ ) daqueles que nunca frequentam. Maior frequência a serviços religiosos também se associou a maiores niveis de suporte social. A associação entre maior frequência e menos transtorno mental comum não sofreu alteraçôes relevantes após inclusão das variáveis de suporte social. Conclusão: A amostra apresentou altos niveis de religiosidade, forte associação entre freqüência religiosa e menor prevalência de transtornos mentais comuns, que não foi explicada pelo suporte social.

Descritores: Espiritualidade; Idoso; Saúde mental; Apoio social; Saúde mental
Submitted: August 13, 2009

Accepted: June 15, 2010

\section{Correspondence}

Alexandre Augusto Macêdo Corrêa Rua João Carriço, 120/304 - Centro 36016-190 Juiz de Fora, MG, Brazil

Phone: (+55 32) 3232-5763 / 8808-4145

E-mail: alexandre.correa@ufjf.edu.br 


\section{Introduction}

Increasingly, research suggests that religiosity and spirituality are relevant factors in people's lives, especially when they are ill or in suffering. Study reviews have indicated that religiosity may be related to better well-being, lower prevalence and better outcome of mental disorders, as well as to lower suicide rates, delinquency, drug abuse and mortality in general. The strength of the inverse correlation between religiosity and mental disorders has been stronger in populations under stress-generating conditions such as physical disabilities and poverty. ${ }^{1-2}$

In the present study, we adopted the concept of religion as an organized system of practices, rituals, beliefs and symbols that are designed to facilitate closeness to the sacred or transcendent, understanding spirituality as a personal quest for answers about the meaning of life and the relationship with the sacred or transcendent. While the different dimensions of religiosity can be investigated, the following dimensions are the most widely studied: subjective religiosity (how religious an individual considers himself to be), religious denomination (religion practiced by an individual) and organized religiosity (how often an individual goes to church and attends religious services or other religious activities). This last dimension has been shown to be the most consistently associated with positive health indicators. ${ }^{3}$

Among the mechanisms which have been proposed to explain the influence of religiosity on one's health, we find social support, healthy habits/lifestyle and the cognitive schemes provided by religiosity. ${ }^{3}$ A review of the potential mediator role of such factors has generated mixed and inconsistent results, thus suggesting the need for a more thorough investigation of such mechanisms. ${ }^{4}$ The theory that states that social support mediates the connection between religion and mental health is compatible with the perception that the dimension of religiosity relating to attendance of religious services is probably the strongest predictor of health and mortality. Apparently, attendance of religious services increases the probability of developing a social support network. ${ }^{5}$

Among the various aspects related to social support that have been mentioned as possible predictors of health and well-being one can find the following: the structure provided by our own social network, the support we receive from others, the social support we offer to others, the quality and number of social interactions, and feelings of loneliness and isolation. ${ }^{5}$ It has been noticed that, normally, individuals with higher levels of religiosity present higher levels of social support. ${ }^{6}$ In another study comparing the effects of religiosity on health and well-being, results have shown that, regardless of their denominations, people who identify themselves as religious beings report that they are healthier and happier and that they have more social support on which to rely.

Given the association between social support and religiosity and better health, the question remains as to the possible role played by social support as a mechanism through which religious involvement impacts health and longevity. Some studies suggest that there may be something relatively exclusive about the social support offered by a religious environment, differentiating religious social support from secular social support. ${ }^{4}$ A religious group can share and contribute to the development of a cognitive approach when one is confronted with the joys and losses of life, which is essentially useful to individuals under stress because this mechanism provides the resources they need in order to find meaning in the facts of life. Furthermore, these are meanings that are socially shared. ${ }^{8}$

In a prospective three-year national study of 1,500 older subjects in America, Krause ${ }^{4}$ investigated the connection between religiosity and its impact on mortality. The frequency of religious attendance was inversely related to mortality. Some studies indicate the existence of an indirect relation between religious attendance and psychological well-being through the religious identity and social support dimensions. ${ }^{9,10}$

Considering the various aspects contemplated so far, we believe that a more thorough investigation of the impact of religiosity on people's health, especially among older populations living outside the European/North American axis, as well as a better understanding of the role played by social support as a mediator of the association between religiosity and mental health are required.

The use of the definition of common mental disorders (CMD) can be very helpful in this investigation about the impact of religiosity on public health. CMD i.e., minor psychiatric disorders, are understood as the presence of symptoms such as irritability, tiredness, insomnia, difficulty of concentration, forgetfulness, anxiety and somatic complaints. CMD affect more than $25 \%$ of the world's population, affecting people of all ages, both genders and different social groups. ${ }^{11}$ These symptoms are extremely relevant for the public healthcare services, they are a major cause of sick leaves, and are commonly seen in the elderly. ${ }^{12}$

The purpose of the present study is to evaluate both the relation between the dimensions of religiosity i.e., the organized, subjective and affiliation aspects of religiosity, and the prevalence of CMD in low income older adults in a large Brazilian city and the role of social support as a mediator of such association.

\section{Method}

\section{Study design and sample}

The present study is part of the cohort study São Paulo Ageing $\&$ Health Study (SPAH), which investigates several aspects of the mental health of individuals aged 65 or older living in low income areas in the city of São Paulo. The main purpose of the first stage of the SPAH, which was conducted between April 2003 and May 2005, was to estimate the prevalence of dementia among the low income elderly living in São Paulo. ${ }^{13}$ The SPAH recruited all residents aged 65 years or older who from 66 census areas in the borough of Butantã, located in the Western part of the city of São Paulo, Brazil. All selected areas had a low human development index, shantytowns or Family Health Strategy Units. In 2000, this area had a population of 63,122 inhabitants, representing $16.7 \%$ of the total population of Butantã. During the first stages of the study, all older adults living in the area under study were identified through census records. From the 2,266 elderly identified, 2,072 $(91.4 \%)$ agreed to take part in the study and were therefore interviewed. The reasons why almost $10 \%$ of the sample refused 
to take part in the study included not wanting to either share private information or participate in the study.

\section{Measurements}

A standard questionnaire was used in order to obtain sociodemographic information on gender, age, level of education, marital status, monthly family income, and self-report on race. Marital status was categorized as married, widowed, divorced or single. The study participants level of education was categorized into three groups, namely no schooling, 1 to 3 years of schooling and 4 or more years of schooling. Results on family income (people living in the same household) were classified according to the following groups: lower than US\$85, from US\$86 to US\$2 46 and higher than US\$247. When asked about their race, participants referred to their skin color as being either Caucasian, Black, Mixed, Asian or Indigenous (Native Brazilian). Other skin colors were considered as "others".

Three questions were used to assess the level of religiosity. The organized religious practice dimension was evaluated using the question Do you take part in religious meetings? (more than or equal to once a week; from 1 to 3 times a month; less than once a month; never); the subjective dimension was measured using the question Do you consider yourself religious? (yes or no), and the religious denomination was identified using the question What is your current religion?

The prevalence of CMD was evaluated through the Selfreport Psychiatric Screening Questionnaire-20 (SRQ). ${ }^{14}$ This self-applicable tool was planned to allow for the screening of mental disorders in primary care services, as well as for use in large epidemiological studies to identify cases of depression and anxiety. Its application to the study's sample was validated ${ }^{14}$ with a sensitivity of $76.1 \%$ and specificity of $74.6 \%$. The presence of CMD was dichotomized into two different scores, namely score $\geq 5$ (possible cases of CMD) and $<5$ (possible non cases of CMD).

Data regarding social support were obtained through standardized interviews and results were dichotomized into interaction with relatives (daily and less than once a day), with neighbors (less than or equal to once a week and more than once a week), with friends (less than or equal to once a week and more than once a week), number of close friends and neighbors (less than or equal to 2 or more than 2) and offered support i.e., if the person looked after someone else apart from him or herself (yes and no) and if he/she was sought after for advice (yes and no).

\section{Statistical analysis}

A binomial logistical regression was used to investigate the association between CMD and the three dimensions of religiosity under controlled socio demographic variables. After that, the different categories of social support (support to or from relatives, friends, neighbors, and offered support) were included in the model - first separately, then together - to evaluate their effect as moderators of the connection between CMD and religiosity. A binomial logistical regression was also used to investigate the association between religious attendance and social support.
Version 13.0 of the SPSS software was used. Statistical significance was examined using likelihood ratio tests. Chi-squares for trend were used. Odds ratios (OR) with 95\% confidence intervals were calculated with logistical regressions.

\section{Ethical aspects}

Participants were recruited only after signing of a free consent form. The terms were read to the illiterate subjects who were then asked to express their consent verbally in the presence of a witness. The SPAH protocol was duly approved by the Brazilian National Committee on Ethical Research - Comissão Nacional de Ética em Pesquisa (CONEP Brasil).

\section{Results}

Table 1 shows the socio-demographic and religious profiles of the studied sample. Sixty percent of the participants were female. $71.5 \%$ ranged between the ages of 65 and $74,74.6 \%$ had a monthly family income equal or lower than $\mathrm{R} \$ 700,52.8 \%$ had spent from 1 to 3 years in school, $46.6 \%$ were married and $37.9 \%$ described themselves as being Caucasian. 90\% reported being religious, $41.2 \%$ attended church or a temple at least once a week. 67\% declared themselves to be Catholic, 25.2\% Evangelical and less than $1 \%$ were atheist or agnostic.

Table 2 demonstrates the characteristics of the social support received by the sample and how these relate to religious attendance. $80.8 \%$ had daily contact with relatives. Just over a third of the sample had been asked for advice by others and 16\% took care of someone else. Higher religious service attendance was associated with stronger social support after controlling for sociodemographics.

Table 3 displays the results of the association between CMD and organized religious practice. The prevalence of CMD among individuals who attend a religious activity was approximately half (OR ranging between 0.43 and $0.55, \mathrm{p}<0.001$ ) compared to those who never do. The association between CMD and religious attendance did not change upon the inclusion of social support into the statistical model.

The religious denomination and subjective religiosity i.e., how religious oneself considers to be, did not statistically associate with the presence of CMD. Therefore, the mediator role of social support was not tested with respect to these dimensions of religiosity.

\section{Discussion}

When investigating the role played by social support in the association between religiosity and mental health in a sample of low income older adults, this study found a high level of religious involvement. Religious denomination and considering oneself as a religious person were not statistically associated with the prevalence of CMD. However, religious attendance presented a strong inverse association with the prevalence of CMD.

The positive aspects of this study include the use of a rigorous and representative sample of the target population and of a CMD scale which was validated within the sample itself, and the fact that 
Table 1 - Social-demographic and subjective and organizational religiosity characteristics and religious affiliation for the participants of the study $(\mathrm{N}=1.980)$

\begin{tabular}{|c|c|}
\hline & $\%(\mathrm{~N})$ \\
\hline \multicolumn{2}{|l|}{ Sex } \\
\hline Female & $60.7 \%(1.202)$ \\
\hline \multicolumn{2}{|l|}{ Age } \\
\hline Average & 71.9 (SD 6) \\
\hline \multicolumn{2}{|l|}{ Marital status } \\
\hline Married & $46.6 \%(922)$ \\
\hline Widowed & $34.8 \%(689)$ \\
\hline Divorced & $15.0 \%(297)$ \\
\hline Single & $3.6 \%(72)$ \\
\hline \multicolumn{2}{|l|}{ Education } \\
\hline No school & $37.5 \%(743)$ \\
\hline $1-3$ years & $52.8 \%(1.046)$ \\
\hline 4 years or more & $9.6 \%(191)$ \\
\hline \multicolumn{2}{|l|}{ Monthly household income } \\
\hline$\leq \$ 85.00$ & $30.3 \%(743)$ \\
\hline$\$ 86.00$ to $\$ 246.00$ & $44.3 \%(877)$ \\
\hline$\$ 247.00$ or more & $25.4 \%(503)$ \\
\hline \multicolumn{2}{|l|}{ Color or race (self referred) } \\
\hline White & $37.9 \%(751)$ \\
\hline Black & $12.2 \%(242)$ \\
\hline Mixed Race & $17.4 \%(345)$ \\
\hline Asian & $2.6 \%(52)$ \\
\hline Native Brazilian & $0.6 \%(11)$ \\
\hline Other & $29.2 \%(583)$ \\
\hline \multicolumn{2}{|l|}{ Dimensions of religiosity } \\
\hline \multicolumn{2}{|l|}{ Subjective } \\
\hline - considers himself/herself religious & $90.7 \%(1.784)$ \\
\hline \multicolumn{2}{|l|}{ Organizational } \\
\hline \multicolumn{2}{|l|}{ - religious attendance* } \\
\hline Never & $26.8 \%(413)$ \\
\hline$<$ once a month & $10.8 \%(166)$ \\
\hline $1-3$ times a month & $21.2 \%(326)$ \\
\hline$\geq 1$ once a month & $41.2 \%(633)$ \\
\hline \multicolumn{2}{|l|}{ Religious affiliation } \\
\hline Catholic & $66.6 \%(1.319)$ \\
\hline Evangelical - Pentecostal & $25.1 \%(496)$ \\
\hline Evangelical - Historic & $2.2 \%(44)$ \\
\hline Buddhist & $1.5 \%(29)$ \\
\hline Atheist/Agnostic & $0.6 \%(11)$ \\
\hline Other & $4.0 \%(81)$ \\
\hline \multicolumn{2}{|l|}{ Another cult ${ }^{* *}$} \\
\hline Spiritualist & $4.3 \%(85)$ \\
\hline Afro-Brazilian & $0.9 \%(17)$ \\
\hline Other & $94.8 \%(1.878)$ \\
\hline
\end{tabular}

* $n=1,538$

${ }^{\star *}$ When asked if they are affiliated to another religion.

this study investigated three of the most important dimensions of religiosity as studied in the literature. ${ }^{3}$ Furthermore, the present study contributes to the expansion of the empirical basis of studies on religiosity and health to regions other than the European/North American regions, especially in a vulnerable population comprised of low income older adults living in a developing country.
In our research, religious denomination was not found to be associated with CMD. In the past decade, most studies tended to report no significant difference in mental health among followers of the various religious denominations. What might explain our results is the low variability in religious denomination found in our sample. Similarly to what is observed in the majority of the Brazilian population, only the Catholic and Protestant denominations have a high number of followers. Another possible explanation might be the so-called "religious porosity", ${ }^{15}$ a phenomenon in which people move between denominations. This characteristic makes it more difficult to make analyses based on the stratification of religious categories.

Pargament clarifies that religion provides many people with motivation, show them what the essential goals in life should be, and provide the guidance they need for reaching them. ${ }^{16}$ In addition, certain aspects of religiosity seem to be positively associated with a sense of meaning to life. ${ }^{17}$ Some studies clearly point to a direct association between subjective religiosity (considering oneself religious) and conjugal satisfaction, whereas there is an inversely proportional association with depression, use of alcohol, illegal drugs and smoking. ${ }^{18,19}$ In our results, subjective religiosity was not found to be statistically associated with the prevalence of CMD. Subjective religiosity was dichotomized into 'yes' or 'no', and the vast majority of interviewees answered 'yes'. This being the case, the group which considered itself to be religious probably included both the highly and the lowly religious. These limitations may have contributed to the decrease in statistical power needed to detect an association, if indeed an association exists. Further studies could provide a wider range of answers allowing for the establishment of more subjective indicators of religious practice.

The sample studied presented high levels of religiosity in the three dimensions investigated. That result was expected due to the high level of religiosity found in Brazil, especially among the older population. ${ }^{20}$ According to international studies, higher levels of mental and physical health were associated with people who attend religious services. ${ }^{5,21}$ That association was also found in our sample of low income older adults in Brazil in which there was a strong inverse association between religious attendance and CMD (OR ranging between 0.43 and 0.55). On one hand, it is possible that lower levels of religious attendance are associated with a lower prevalence of CMD due to the fact that people who are more depressed or ill may not be able to attend religious events. Nonetheless, a prospective study has found that physical disabilities had little impact on religious attendance. ${ }^{13}$ On the other hand, in the same study, religious involvement was prospectively associated with better levels of mental health and lower functional decline. ${ }^{12}$ Bradley, when investigating the relationship between religiosity and longevity, demonstrated that attendance of religious services constitutes a complex structure including different attitudes, beliefs and behaviors, and that any of those factors might explain this relationship. ${ }^{22}$ Idler argues in favor of the need for a better understanding of the nature of 
Table 2 - Correlations between characteristics of Social Support for the participants of the study and their association with religious attendance, controlling for socio-demographic variables $(N=1,538$, except for support related to friends $N=866)$

\begin{tabular}{|c|c|c|c|c|c|c|}
\hline & \multirow[t]{2}{*}{$\%(N)$} & \multicolumn{4}{|c|}{ Religious attendance OR $\left(\mathrm{Cl}^{\star} 95 \%\right)$} & \multirow{2}{*}{$\begin{array}{l}\text { p-value for } \\
\text { linear trend }\end{array}$} \\
\hline & & Never & Once/month & 1-3 times/mo. & $\geq$ once/week & \\
\hline Close friends & & 1 & & & & 0.009 \\
\hline$\leq 2$ & $49.9 \%(432)$ & & 1.22 & 1.05 & 1.49 & \\
\hline$>2$ & $50.1 \%(434)$ & & $(0.72-2.05)$ & $(0.69-1.60)$ & $(1.04-2.14)$ & \\
\hline$\leq$ once/week & $26.5 \%(230)$ & & 0.81 & 1.52 & 1.59 & \\
\hline$\geq 2-3 /$ week & $73.5 \%(636)$ & & $(0.46-1.40)$ & $(0.95-2.43)$ & $(1.06-2.37)$ & \\
\hline \multicolumn{7}{|c|}{ Support related to neighbors } \\
\hline Contact & & 1 & & & & $<0.001$ \\
\hline$\leq$ once/week & $50.4 \%(776)$ & & 1.30 & 1.56 & 1.84 & \\
\hline$>$ once/week & $49.6 \%(762)$ & & $(0.90-1.89)$ & $(1.15-2.11)$ & $(1.41-2.40)$ & \\
\hline$\leq 2$ & $55.3 \%(851)$ & & 1.30 & 1.56 & 1.84 & \\
\hline$>2$ & $44.7 \%(687)$ & & $(0.90-1.89)$ & $(1.15-2.11)$ & $(1.41-2.40)$ & \\
\hline Contact with relatives & & 1 & & & & 0.45 \\
\hline$<$ once/day & $19.6 \%(302)$ & & 0.82 & 0.69 & 0.89 & \\
\hline Daily & $80.4 \%(1,236)$ & & $(0.51-1.31)$ & $(0.47-1.01)$ & $(0.63-1.16)$ & \\
\hline \multicolumn{7}{|l|}{ Support offered } \\
\hline Takes care of someone & & 1 & & & & 0.16 \\
\hline No & $83.8 \%(1.289)$ & & 1.13 & 1.23 & 1.36 & \\
\hline Yes & $16.2 \%(249)$ & & $(0.64-2.00)$ & $(0.79-1.92)$ & $(0.92-2.00)$ & \\
\hline Been asked for advice & & 1 & & & & $<0.001$ \\
\hline No & $61.4 \%(945)$ & & 0.95 & 1.23 & 1.72 & \\
\hline Yes & $38.6 \%(593)$ & & $(0.63-1.41)$ & $(0.90-1.69)$ & $(1.31-2.26)$ & \\
\hline
\end{tabular}

religious services and the psychological dimensions of its activities, and points out to the difficulty of working with just one religious service attendance indicator. ${ }^{12}$ Ness and Larson add that, for older people, the relationship between religiosity and social support may be explained by the fact that they have more time available to engage in these activities and that, for them, religious activities serve as forms of socialization. ${ }^{23}$ Furthermore, religion can promote a welcoming and trusting interpersonal space, making it easier for its members to reach out to each other at the most difficult moments. ${ }^{4}$

Krause shows us that, for the elderly, the support they receive from other people has become a significant source of assistance in a way that they can deal with the negative effects of stress in a more effective manner. ${ }^{10}$ In the present study, the attendance of religious events was associated with several measures of social support. Given the transversal character of the investigation, it is not possible to establish the directions of such association. Higher levels of organized religiosity may be just a marker of a more pro-social behavior. However, these may also promote greater social interaction. Our assessment of social support was limited to evaluating social support in general, i.e., without investigating the kind of support that is specifically related to the religious context. Ellison and George state that religious social relations have specific characteristics, being different from secular social relations because they possess shared beliefs and values which suggest more support and care among its members. ${ }^{14}$ Religious involvement may promote certain behaviors or attitudes that increase happiness, satisfaction and general well-being. Such associations between religious involvement and behavior and attitudes may explain how religion is able to achieve this. By taking these relations into consideration, we may improve the health care that is provided to the elderly.

Although in our sample social support dimensions were, in general, associated with organized religiosity, it did not mediate the association between CMD and religious attendance since the inclusion of variables of social support in the model did not significantly alter results. Several studies on religiosity and the relation with psychological well-being and mortality have found that the inclusion of variables of social support in the model significantly decreases the strength of this association, thus suggesting that social support may be an important mediator between religiosity and health. ${ }^{1,5}$ Koenig et al., when examining social support and physical health as possible mediators between religiosity and depressive symptoms report that religious attendance was negatively associated with symptoms of depression and positively associated with physical health. ${ }^{24}$ However, it was 
Table 3 - Logistic regressions testing the association between Religious Attendance and the presence of common mental disorders (CMD), testing the several kinds of social support as possible mediators (SRQ $\geq 5$ )

\begin{tabular}{|c|c|c|c|c|c|c|}
\hline & $\begin{array}{c}\text { Model I* } \\
\text { OR (Cl** } 95 \%)\end{array}$ & $\begin{array}{l}\text { Model II** } \\
\text { OR (CI 95\%) }\end{array}$ & $\begin{array}{l}\text { Model III** } \\
\text { OR (CI 95\%) }\end{array}$ & $\begin{array}{l}\text { Model IV* } \\
\text { OR (CI 95\%) }\end{array}$ & $\begin{array}{l}\text { Model V* } \\
\text { OR (CI 95\%) }\end{array}$ & $\begin{array}{l}\text { Model VI** } \\
\text { OR (CI 95\%) }\end{array}$ \\
\hline \multicolumn{7}{|l|}{$\begin{array}{l}\text { Religious } \\
\text { attendance }\end{array}$} \\
\hline Never & 1 & 1 & 1 & 1 & 1 & 1 \\
\hline$<$ once a month & $0.43(0.28-0.65)$ & $0.36(0.19-0.65)$ & $0.43(0.28-0.65)$ & $0.43(0.28-0.65)$ & $0.43(0.28-0.65)$ & $0.36(0.19-0.66)$ \\
\hline $1-3$ times a month & $0.55(0.40-0.76)$ & $0.60(0.38-0.94)$ & $0.55(0.40-0.77)$ & $0.55(0.40-0.76)$ & $0.55(0.39-0.76)$ & $0.60(0.38-0.95)$ \\
\hline$\geq 1$ once a week & $0.52(0.40-0.70)$ & $0.53(0.35-0.77)$ & $0.53(0.40-0.70)$ & $0.52(0.40-0.69)$ & $0.52(0.39-0.69)$ & $0.53(0.36-0.78)$ \\
\hline \multicolumn{7}{|l|}{$\begin{array}{l}\text { Support related to } \\
\text { friends }\end{array}$} \\
\hline \multicolumn{7}{|l|}{ Close friends } \\
\hline$\leq 2$ & & 1 & & & & 1 \\
\hline$>2$ & & $1.05(0.77-1.42)$ & & & & $1.02(0.75-1.39)$ \\
\hline \multicolumn{7}{|l|}{ Contact } \\
\hline$\leq$ once/month & & 1 & & & & 1 \\
\hline$\geq 2-3 /$ week & & $0.60(0.43-0.84)$ & & & & $0.62(0.44-0.88)$ \\
\hline \multicolumn{7}{|l|}{$\begin{array}{l}\text { Support related to } \\
\text { neighbors }\end{array}$} \\
\hline \multicolumn{7}{|l|}{ Contact } \\
\hline$\leq$ once/week & & & 1 & & & 1 \\
\hline > once/week & & & $0.88(0.69-1.11)$ & & & $0.84(0.60-1.18)$ \\
\hline \multicolumn{7}{|l|}{ Close-by neighbors } \\
\hline$\leq 2$ & & & 1 & & & 1 \\
\hline$>2$ & & & $1,02(0.81-1.30)$ & & & $1.14(0.82-1.57)$ \\
\hline \multicolumn{7}{|l|}{$\begin{array}{l}\text { Contact with } \\
\text { relatives }\end{array}$} \\
\hline$<$ once/day & & & & 1 & & 1 \\
\hline Daily & & & & $1.08(0.80-1.44)$ & & $0.96(0.63-1.47)$ \\
\hline \multicolumn{7}{|l|}{ Offered support } \\
\hline \multicolumn{7}{|l|}{$\begin{array}{l}\text { Takes care of } \\
\text { someone }\end{array}$} \\
\hline No & & & & & 1 & 1 \\
\hline Yes & & & & & $0.84(0.62-1.15)$ & $0.79(0.53-1.17)$ \\
\hline \multicolumn{7}{|l|}{ Gives advice } \\
\hline No & & & & & 1 & 1 \\
\hline Yes & & & & & $1.12(0.89-1.42)$ & $1.24(0.91-1.70)$ \\
\hline
\end{tabular}

MODEL I: Controlled for the socio-demographics variables: sex, age, education, income, marital status and color (or race); MODEL II: Controlled for Support from friends and Socio demographics; MODEL III: Controlled for Support from neighbors and Socio demographics; MODEL IV: Controlled for Contact with Relatives and Socio demographics; MODEL V: Controlled for Support Offered and Socio demographics; MODEL VI: Controlled for all variables of Social Support and Socio demographics.

${ }^{*} \mathrm{~N}=1,534 ;{ }^{* *} \mathrm{~N}=864 ;{ }^{* * *} \mathrm{Cl}=$ Confidence Interval

Statistically significant results are in bold types.

physical health instead of social support which appeared as the mediator between religion and depressive symptoms.

Another aspect which deserves to be emphasized is that studies have concentrated on the support received. Nevertheless, providing help may have more positive consequences than receiving support. ${ }^{25}$ When identifying the mediating effect of social support in the inverse relation between religious attendance and mortality in the elderly, Krause tried to identify the causes of the inconstancy between his results and the data found in the several studies in which social support did not present a mediating effect. ${ }^{26} \mathrm{He}$ reported that researchers have normally used measurements which assess the social support of a person as a whole of his/her social networks, both, inside and outside religious institutions. Besides, the models tested by researchers to assess social support did not consider the additional effects of stress since the potentially beneficial effect of social support may only become evident under stressful situations. Last but not least, previous studies only assessed support received. Krause found that there is a stronger association between offered support and physical and mental health than between the latter and support received. ${ }^{26}$ Helping others may increase the self-esteem of those who offer support and help them to resolve and overcome their own problems, with similar results in the person who received the support. ${ }^{26}$

The present and future use of several dimensions of social support and its differentiation into social integration (time 
spent providing support to members of a same network), instrumental support (the importance of the task performed) and subjective social support (quality of social support), as well as the distinction between support received and support offered allowed for a better understanding of the role played by social support as a possible mediator between religiosity and mental health The transversal character of this study has put in check the causal inference that higher religious attendance leads to a lower prevalence of CMD. However, other longitudinal studies support this hypothesis. ${ }^{3}$ Although the attendance of religious events has become associated with better mental health, it is necessary to further explore the mediating mechanisms. Our initial hypothesis that social support at least partly mediated this association has not been confirmed.

\section{Conclusion}

A high level of religiosity was identified in the sample, as well as a strong impact of religious attendance in the prevalence of CMD though another way other than the mere increase of social support. Religious affiliation and considering oneself religious did not present a significant association with CMD.

Perceiving religiosity as a variable that interferes in mental health is to change the relationship many times established between researchers and healthcare professionals with religious communities. In the same way that mental health professionals have not valued the role of religion in people's lives, religious communities have also frequently developed negative attitudes regarding mental health professionals, who are normally seen as useless or a menace to their religious beliefs and convictions.

Therefore, due to the importance of religiosity and its consequences in the field of mental health, and its relations and implications on public health, one can notice the importance of developing scientific knowledge on the issue as well as on the religious profile, its impact on older adults, and a better exploration of the role of social support in the impact of religiosity on health. Also, the lack of Latin-American data on the relationship between religiosity and mental health in elderly people is evident, constituting into a large and unexplored field of study and research.

\section{Disclosures}

\begin{tabular}{|c|c|c|c|c|c|c|c|}
\hline $\begin{array}{l}\text { Writing group } \\
\text { member }\end{array}$ & Employment & $\begin{array}{l}\text { Research } \\
\text { grant }^{1}\end{array}$ & $\begin{array}{c}\text { Other research grant or } \\
\text { medical continuous } \\
\text { education }\end{array}$ & $\begin{array}{l}\text { Speaker's } \\
\text { honoraria }\end{array}$ & $\begin{array}{l}\text { Ownership } \\
\text { interest }\end{array}$ & $\begin{array}{l}\text { Consultant/ } \\
\text { Advisory } \\
\text { board }\end{array}$ & Other $^{3}$ \\
\hline $\begin{array}{l}\text { Alexandre } \\
\text { Augusto Macêdo } \\
\text { Corrêa }\end{array}$ & UNIPAC & - & - & - & - & - & - \\
\hline $\begin{array}{l}\text { Alexander Moreira } \\
\text { de Almeida }\end{array}$ & UFJF & - & - & - & - & - & - \\
\hline Paulo R. Menezes & USP & - & - & - & - & - & - \\
\hline Homero Vallada & IPq-HC-FMUSP & - & - & - & - & - & - \\
\hline Marcia Scazufca & USP & - & - & - & - & - & - \\
\hline \multicolumn{8}{|c|}{$\begin{array}{l}\text { *Modest } \\
\text { ** Significant } \\
\text { *** Significant: Amounts given to the author's institution or to a colleague for research in which the author has participation, not directly to the } \\
\text { author. } \\
\text { Note: UNIPAC = Universidade Presidente Antônio Carlos; UFJF = Universidade Federal de Juiz de Fora; USP = Universidade de São Paulo; } \\
\text { IPq-HC-FMUSP = Instituto de Psiquiatria, Hospital das Clinicas, Faculdade de Medicina, Universidade de São Paulo. } \\
\text { For more information, see Instructions for Authors. }\end{array}$} \\
\hline
\end{tabular}

\section{References}

1. McCullough ME, Hoyt WT, Larson DB, Koenig HG, Thoresen C. Religious involvement and mortality: a meta-analytic review. Health Psychol. 2000;19(3):211-22. 2. Moreira-Almeida A, Neto FL, Koening HG. Religiousness and mental health: a review. Rev Bras Psiquiatr. 2006;28(3):242-50.

3. Koenig HG, McCulloug M, Larson DB. Handbook of religion and health: a century of research reviewed. New York: Oxford University Press; 2001.

4. Krause N. Exploring the stress-buffering effects of church-based and secular social support on self-rated health in late life. J Gerontol B Psychol Sci Soc Sci. 2006;61(1):S35-43.

5. George LK, Ellison CG, Larson DB. Explaining the relationships between religious involvement and health. Psychological Inquiry. 2002;13(03):190-200.

6. Cohen S. Social relationships and health. Am Psychol. 2004;59(8):676-84.

7. Krause N. Social support. In: Binstock R H, George L K. editors. Handbook of aging and the social science. 5th ed. San Diego, CA: Academic Press; 2001. p.272-94.

8. Green M, Elliott M. Religion, health, and psychological well-being. J Relig Health. In press 2009.
9. Idler EL, Kasl SV. Religion among disabled and nondisabled persons II: attendance at religious services as a predictor of the course of disability. J Gerontol B Psychol Sci Soc Sci. 1997;52(6):S306-16.

10. Ellison CG, George LK. Religious involvement, social ties, and social support in a southeastern community. J Sci Study Religion. 1994;33:46-61.

11. Krause N, Wulff KM. Religious doubt and health: exploring the potencial dark side of religion. Soc Religion. 2004;65(1):35-56.

12. Ludermir AB, Melo Filho DA. Living conditions and occupational organization associated with common mental disorders. Rev Saude Publica. 2002;36(2):213-21.

13. Scazufca M, Menezes PR, Araya R, Di Rienzo VD, Almeida OP, Gunnell D, Lawlor DA; Sao Paulo Ageing \& Health Study. Risk factors across the life course and dementia in a Brazilian population: results from the Sao Paulo Ageing $\&$ Health Study (SPAH). Int J Epidemiol. 2008;37(4):879-90.

14. Scazufca M, Menezes PR, Vallada H, Araya R. Validity of the self reporting questionnaire-20 in epidemiological studies with older adults: results from the Sao Paulo Ageing \& Health Study. Soc Psychiatry Psychiatr Epidemiol. 2009; 44(3):247-54.

15. Sanchis P. A religião dos brasileiros. Teoria e Sociedade. 2003; especial:16-49. 
16. Pargament KI. The psychology of religion and coping: theory, research, practice. New York: Guilford Press; 1997.

17. Ardelt M. Effects of religion and purpose in life on elders subjective well-being and attitudes toward death. J Religious Gerontol. 2003;14:55-77.

18. Lawler-Row KA, Elliott J. The role of religious activity and spirituality in the health and well-being of older adults. J Health Psychol. 2009;14(1):43-52.

19. Tavares BF, Beria JU, Lima MS. [Factors associated with drug use among adolescent students in southern Brazil]. Rev Saude Publica. 2004;38(6):787-96.

20. Dalgalarrondo P. Religiāo, psicopatologia e saúde mental. Artmed; 2008.

21. Ellison CG, Levin JS. The religion-health connection: evidence, theory, and future directions. Health Educ Behav. 1998;25(6):700-20.

22. Bradley WJ, Schaefer KC. The uses and misuses of data and models: the mat hematization of the human sciences. Thousand Oaks: Sage; 1998.

23. Van Ness PH, Larson DB. Religion, senescence, and mental health: the end of life is not the end of hope. Am J Geriatr Psychiatry. 2002;10(4):386-97.

24. Koenig HG, Hays JC, George LK, Blazer DG, Larson DB, Landerman LR. Modeling the cross-sectional relationships between religion, physical health, social support, and depressive symptoms. Am J Geriatr Psychiatry. 1997;5(2):131-44.

25. Park CL. Religiosity/spirituality and health: a meaning systems perspective. $J$ Behav Med. 2007;30(4):319-28.

26. Krause N. Church-based social support and mortality. J Gerontol B Psychol Sci Soc Sci. 2006;61(3):S140-6. 